\title{
Parasite removal rates by the cleaner wrasse Labroides dimidiatus
}

\author{
Alexandra Grutter* \\ Department of Marine Biology, James Cook University of North Queensland, Townsville, Queensland 4811, Australia
}

\begin{abstract}
The rate at which parasites (mainly gnathiid isopod larvae) were removed from fish by the cleaner wrasse Labroides dimidiatus was investigated. To examine the effect of this parasite removal on the parasites of fish, the number of parasites removed per individual host fish Hemigymnus melapterus per day was estimated and compared to the infection rate and abundance of gnathiids on H. melapterus. The study was conducted at Lizard Island, Great Barrier Reef, Australia, using a combination of observations of the feeding rates of cleaners, estimates of how much time individual hosts spend being cleaned, cleaner fish stomach content analyses, and a gnathiid manipulation experiment. The frequency and duration of inspection by $L$. dimidiatus were measured to provide an estimate of the feeding rate. Individual $L$. dimidiatus spent on average $256 \pm 11$ (SE) $\mathrm{min}^{-1}$ inspecting $2297 \pm 83$ fish. L. dimidiatus consumed a large number of parasites (1218 \pm 118 , mainly gnathiid isopods) each day The estimated predation rate by $L$. dimidiatus was $4.8 \pm 0.4$ parasites per minute of inspection or $0.5 \pm$ 0.05 parasites per inspection. The infection rate of gnathiids onto fish was high. with reduced gnathiid loads (by about $50 \%$ ) on fish returning to levels similar to control fish within 1 to $6 \mathrm{~d}$. These high infection rates suggest that a significant proportion of gnathilds removed by cleaner fish are quickly replaced. The high predation rate relative to the number of gnathiids on fish and their infection rate shows that cleaner fish have an effect on the abundance of gnathiids on fish.
\end{abstract}

KEY WORDS: Cleaning symbiosis - Fish behaviour - Labroides dimidiatus Predation rate - Infection rate Parasites - Gnathiid isopods

\section{INTRODUCTION}

To understand the ecological significance of cleaning behaviour in reef fish, information on the effect of cleaner fish on parasites is needed. How cleaner fish affect parasites is dependent on the rates at which parasites are removed by cleaner fish and added through colonization. Examining the rates and processes involved in parasite removal and infection provides insight into the mechanisms involved in cleaner-fish/ parasite interactions; however, few workers have taken this approach.

The effect of cleaners on host fish has been measured by removing all cleaner fish from reefs and measuring the subsequent effect on host fish (Limbaugh 1961, Youngbluth 1968, Losey 1972, Gorlick et al. 1987, Grutter 1996a). Of these, only Gorlick et al.

\footnotetext{
•E-mail: a.grutter@mailbox.uq.oz.au
}

(1987) have been able to demonstrate quantitatively an effect of a cleaner fish on an ectoparasite in the field. They found that cleaner fish influenced the size frequency distribution of a parasite species on a fish species, with fish having larger parasites in the absence of cleaner fish. Such studies provide information on the long-term effects of cleaners on fish. However, to understand what produces these effects, information on processes involved in the removal of parasites is needed.

The rate at which parasites are removed from fish (predation rate) provides information on the short-term dynamics of parasites in cleaning interactions. Two approaches have been used to measure rates of predation on parasites by cleaner fish. Gut content has been used as a measure of the amount of food eaten daily in conjunction with estimates of densities of cleaner fish and host fish (to calculate predation rates per $\mathrm{m}^{2}$ of reef area and per host fish per day) (Losey 1974). Estimates 
of daily consumption by temperate cleaner fish have been obtained by estimating the number of parasites on fish before and after adding cleaner fish to caged salmon (Treasurer 1994). However, both these estimates are probably conservative because the former does not account for the movement of food through the gut and the latter does not account for the potential turnover of parasites on fish.

Rates of predation on parasites by cleaner fish can also be obtained using a combination of diet analyses and cleaner fish feeding rates. Such an approach also provides insight into the feeding biology of cleaner fish. Diet analyses made throughout the day and corroborated with an estimate of the time required for food to pass through the digestive tract provide a more reliable estimate of the food eaten per unit time. Feeding rates of cleaner fish can be estimated using the duration of inspection of hosts as this is correlated with the number of bites taken by cleaner fish (Youngbluth 1968, Losey 1971). The predation rate is, thus, the number of parasites eaten per unit time of inspection. by cleaners. This is calculated by dividing the number of parasites eaten per unit time by the feeding rate (duration of inspection) of cleaners per unit time. Coral reef fish behaviour often varies throughout the day (Polunin \& Klumpp 1989, Hobson 1991, Choat \& Clements 1993). By repeating observations of inspection behaviour by cleaner fish throughout the day, temporal variation in feeding rates is accounted for, resulting in a more accurate estimate of predation rates by cleaner fish.

The number of parasites removed per individual fish per day can be estimated using predation rates and estimates of the amount of time individual hosts spend being inspected by Labroides dimidiatus per unit time (Grutter 1995a). Information on the infection rate provides an estimate of the rate at which parasites removed by cleaner fish are replaced through colonization. The rate of infection of parasites onto host fish can be estimated by reducing the number of parasites on fish and assessing the time required for parasite levels to return to normal. These estimates of predation rates by cleaner fish and infection rates of parasites. when combined with information on the gnathiid loads of fish, provide insight into the potential impact of cleaner fish on gnathiid abundance on host fish. This method is particularly useful for examining the effect of cleaner fish on mobile fish species as these species cannot be used in traditional cleaner fish removal experiments.

This study estimates the rate at which parasites (mainly gnathiids) are removed by the cleaner wrasse Labroides dimidiatus from host fish using observations of the feeding rates of cleaner fish, diet analyses, and estimates of the amount of time individual host fish spend being cleaned. The effect of parasite removal on the abundance of parasites on fish is explored using estimates of (a) the total number of parasites removed per individual fish per day, (b) the number of gnathiids on fish, and (c) the rate of infection of gnathiids onto fish. The parasite predation rate by $L$. dimidiatus is calibrated for changes in feeding rates throughout the day and is corroborated with an estimate of the rate of passage of food through the digestive tract. The fish species Hemigymnus melapterus is used in this study because its parasite assemblage is well known and includes gnathiid isopods (Grutter 1994) and because information on procedures for manipulating the abundance of gnathiids on this species is available (Grutter 1996b).

\section{METHODS AND MATERIALS}

Feeding rates. The duration of cleaner fish inspection of host fish, which involved visual examination of the body surfaces and or gills of host fish, was used as an estimate of amount of feeding by Labroides dimidiatus. The duration and frequency of inspection were tested for temporal differences within and among days. This information was also used to estimate the total duration of inspection and the total frequency of inspections per day per $L$. dimidiatus and for calculating the rate of predation on parasites per unit time of inspection. The length of an inspection event was determined from the time when a cleaner fish approached a host fish until it departed the host.

Eight adult Labroides dimidiatus were selected haphazardly at North Point on Lizard Island, Australia $\left(14^{\circ} 40^{\prime} \mathrm{S}, 145^{\circ} 26^{\prime} \mathrm{E}\right)$, along the reef crest and slope (2 to $7 \mathrm{~m}$ ) and their locations marked on a map. Cleaner fish and host fish were given 1 to 2 min to habituate to diver presence prior to commencing observations. A total of $50 \mathrm{~h}$ of observations were made by 2 observers. Each $L$. dimidiatus was observed for 15 min from a distance of 3 to $5 \mathrm{~m}$. The duration of each inspection of a host fish by $L$. dimidiatus was recorded and the frequency of inspections calculated from these. The observations were made during 5 time periods (05:45-8:00, 08:15-10:45, 11:30-13:15, 15:00-17:10, and $17: 10-19: 00 \mathrm{~h}$ ) to account for temporal variation in inspection rates.

Observations were made in December-January on 30 December 1992, and 2 and 10 January 1993. To determine whether these estimates were representative of cleaning rates throughout the year, 2 additional days of observations were made on 24 July 1993 and 27 October 1993. To examine the relationship between the duration of inspection and the number of bites taken by Labroides dimidiatus, the number of bites 
taken by $L$. dimidiatus was also recorded by 1 observer on 27 October 1993

Parasite ingestion rate. To calculate the number of parasites eaten by adult Labroides dimidiatus per unit time, cleaner fish were collected throughout the day. Collections of fish began and ended when fish left and entered their sleeping holes. Fish ( $\mathrm{n}=7$ to 9) were collected during 6 periods (06:00-06:59, 09:00-9:59, 10:00-11:59, 13:00-13:59, 14:00-15:59, 16:00-17:59 h) on 5 days in November 1993. The number of parasites in their digestive tract was quantified following Grutter (1995b). The heads of gnathiid isopods were used to estimate gnathiid abundance as heads remain intact throughout the gut.

Gut clearance rate. To estimate the rate of food passage through the digestive tract of adult Labroides dimidiatus, the gut was labelled with empty Artemia cysts mixed with live Artemia to ensure ingestion. This feeding experiment was conducted in the field. Artemia and cysts were held in a 2 l quick-seal plastic bag which was opened briefly, 50 to $150 \mathrm{~cm}$ from $L$. dimidiatus, releasing several hundred live Artemia and cysts which were immediately eaten by L. dimidiatus. Fish ( $\mathrm{n}=6$ to 9 per time interval) were then collected at subsequent time intervals for diet analyses $(0$, $1-2,2-3,3-4$, and $4-7 \mathrm{~h}$ ). The whole gut was divided into 5 equal segments and the number of cysts in each segment was quantified. The proportion of cysts in each segment was plotted against time to estimate the time required for cysts to pass through the gut. Fish were collected from North Point in January 1993

Number of parasites removed per individual fish per day. The number of parasites removed per individual Hemigymnus melapterus per day was estimated with the product of the predation rate (number of parasites eaten per unit time of inspection; see 'Statistical analyses' section) and the amount of time individual hosts spent being inspected by cleaner fish per day. The amount of time individual fish (10 to $15 \mathrm{~cm}$ ) were inspected per day was estimated by multiplying the average duration that $H$. melapterus were inspected per $30 \mathrm{~min}[30.6 \pm(\mathrm{SE}) 0.625 \mathrm{~s}$, which was not significantly different throughout the day; Grutter 1995a], by the average number of waking hours of Labroides dimidiatus (12.65 $\pm 0.04 \mathrm{~h})$.

Parasite infection rate. The rate of infection of gnathiids onto the host fish Hemigymnus melapterus was estimated by measuring the time required for reduced levels of gnathiid isopods on treated fish to return to normal and comparing these with control fish. Treated fish $(n=7)$ were captured with a net, immediately placed in separate plastic bags, and taken to the boat (following Grutter 1996b). The number of gnathiids was reduced by placing each fish in a shaded container with seawater (10 to 20 l) for 2 h (Grutter 1996b). This method has been shown to reduce the number of gnathiids on this fish species by $73 \pm 7.6 \%$ (Grutter 1996b). Fish were tagged (see below) and recaptured 1 to 16 d later.

Control fish ( $n=20$ ) were captured as above but not released. Nine of the control fish were left in plastic bags and all their parasites quantified. To estimate the proportion of gnathiids removed above, the parasite loads of the remaining control fish $(n=11)$ were reduced as above. However, these fish were not released but were retained to quantify the parasites remaining on their body. This experiment was conducted between December 1992 and January 1993 on 2 large patch reefs (approximately $180 \times 100 \mathrm{~m}$ and $75 \times 100 \mathrm{~m})$.

Tagging. In order to recapture treated individuals, Hemigymnus melapterus were tagged by a dermal injection of acrylic paint (Vynol-Derivan, Alexandria, Australia) on the operculum. Two 5 to $8 \mathrm{~mm}$ stripes of different colored paint were used on each operculum to aid in the identification of individual fish. During tagging, fish were held in 21 quick-seal plastic bags with some seawater to reduce handling stress and to contain parasites.

Statistical analyses. The sum of the duration of all inspections per observation ( $15 \mathrm{~min})$ was used in all analyses. Separate univariate repeated-measures analyses were used to test for differences in the duration and in the frequency of inspection per observation period among times periods of day and among the 5 days. The above analyses were repeated with only the 3 days in December-January in order to avoid any potential seasonal confounding effects when calculating predation rates for December-January, and to determine whether or not to average across times of day and days when calculating the mean duration and frequency inspection. Outliers had a marked effect on the homogeneity of variance among treatments [Mauchly's sphericity test applied to orthogonal components had significant $\chi^{2}$ values $(p<0.05)$ ], but these could not be omitted because univariate repeatedmeasures analyses cannot be run with missing values (SAS 1991). The study also required estimates of the normal feeding rates of cleaner fish which could be biased by outliers. Therefore, outliers (values 2 to 6 times higher than the mean) were replaced with means and these data were used in all analyses. Sphericity tests conducted without outliers indicated that the assumption of homogeneity of variance was satisfied. Two outliers in the duration of inspection (1533 and 1664 s) were replaced with the overall mean (280 s) and 1 outlier for the frequency of inspection (127) was replaced with the overall mean (52.5). Because unadjusted tests in univariate repeated-measures analyses are extremely sensitive to the assumption of sphericity, 
the Greenhouse-Geisser adjusted procedure for the significance test was used as it maintains Type 1 error rate at or below the nominal value (Maxwell \& Delaney 1990). The beginning and end of the day were defined as the mean time fish were observed leaving and entering their sleeping holes respectively.

The predation rate of Labroides dimidiatus (number of parasites eaten per unit time of inspection) was estimated by dividing the number of parasites in a full gut by the inspection time required to achieve a full gut. It was assumed that the gut was full when parasite numbers in the diet reached a maximum (the time required to achieve a full gut was compared with the estimate of the food passage rate to determine whether gut evacuation occurred before the gut was full). To find the maxima, the total number of parasites per gut was plotted against time of collection and a line fitted using locally weighted regression scatter-plot smoothing (LOWESS regression; Trexler \& Travis 1993). The peak in the above plot was assumed to represent a full gut. The standard error of this value was calculated using the number of parasites in the diet of fish collected around this time $(n=10)$. It was assumed that the efficiency of cleaner fish predation is the same throughout the day.

To estimate the total number of parasites eaten per individual cleaner fish per day the predation rate was multiplied by the mean total duration of inspection per day (see 'Results' for calculation of latter). The number of parasites removed per fish inspected was calculated by dividing the mean total number of parasites eaten per day by the mean total frequency of inspections per day (see 'Results' for calculation of latter). Appropriate standard errors were calculated for the above estimations (Parratt 1966).

An analysis of covariance (ANCOVA) was used to test whether the number of parasites on recaptured fish was the same as on control fish with standard length of fish (SL) as the covariate. The same analysis was used to test for differences in the cumulative number of gnathiids recovered from treated fish (parasites in container plus on recaptured fish) and the number of gnathiids on controls. The slopes were not significantly different in both ANCOVAs ( $p=0.342$ and $p=0.293$ respectively) so the interaction term was dropped (SAS 1991). For the ANCOVAs, data were natural log transformed to satisfy the assumption of linearity.

\section{RESULTS}

\section{Feeding rates}

The duration of inspection by cleaner fish did not differ among times of day nor among the 5 days
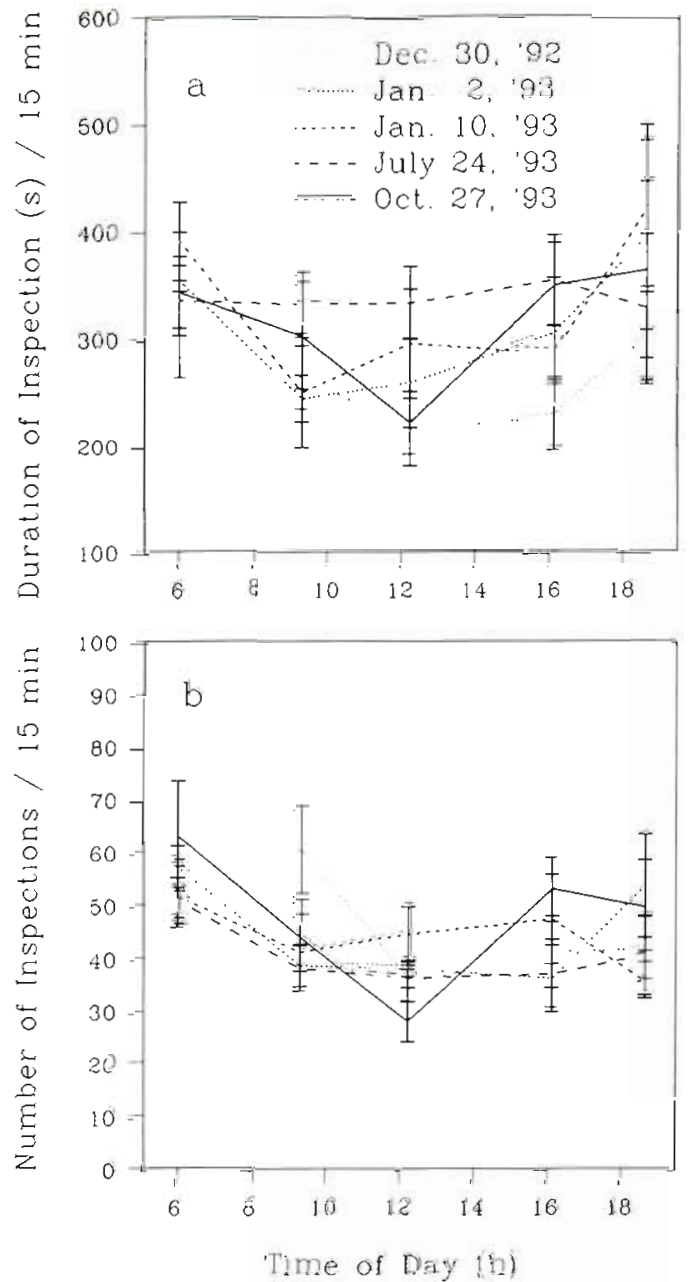

Fig. 1. Labroides dimidiatus. Inspection rates by cleaner fish during several time periods of day and on several days. (a) Sum of the duration of all inspections per 15 min observation period. (b) Number of inspections per 15 min observation period. Error bars show $\pm \mathrm{SE}$

(Table 1a). However, the interaction term (Time of day $\times$ Day) was significant (Table 1a), which indicates the duration of inspection among times of day was not the same over all days. This is likely due to inspections on 24 July which were higher during the midday hours compared with other days (Fig. 1a). Among the 3 days in December-January, there was no significant difference in the duration of inspection among times of day nor days (Table 1 b), therefore the mean duration of inspection was calculated by averaging across times of day and days [303 \pm (SE) $13 \mathrm{~s} / 15$ min].

The estimated mean total duration of inspection by cleaner fish per day was $256 \pm 11 \mathrm{~min}$ and includes all host fish species inspected in a day. This estimate is based on a daily activity of $12.65 \pm 0.04 \mathrm{~h}$, determined from the mean time that cleaners left and entered their sleeping holes $106.03 \pm 0.02$ and $18.68 \pm 0.04 \mathrm{~h}$ respectively). 
Table 1. Labroides dimidiatus. Univariate repeated-measures analysis testing for differences in the duration of inspection (summed over $15 \mathrm{~min}$ ) by cleaner fish among time periods of day and among days. (a) Duration of inspection on 5 days. (b) Duration of inspection on 3 of the 5 days (December-January)

\begin{tabular}{|lccc|}
\hline Source & $F$ & $\mathrm{df}$ & $\mathrm{p}$ \\
\hline (a) & & & \\
Time of day (T) & 0.47 & 4,28 & 0.685 \\
Day (D) & 1.66 & 4.28 & 0.233 \\
$\mathrm{~T} \times \mathrm{D}$ & 14.26 & 16,112 & 0.001 \\
& & & \\
(b) & & & \\
$\mathrm{T}$ & 2.51 & 4,28 & 0.124 \\
$\mathrm{D}$ & 3.84 & 2,14 & 0.054 \\
$\mathrm{~T} \times \mathrm{D}$ & 0.73 & 8,56 & 0.585 \\
\hline
\end{tabular}

Table 2. Labroides dimidiatus. Univariate repeated-measures analysis testing for differences in the frequency of inspection (per $15 \mathrm{~min}$ ) by cleaner fish among time periods of day and among days. (a) Frequency of inspection on 5 days. (b) Frequency of inspection on 3 of the 5 days (December-January)

\begin{tabular}{|lccc|}
\hline Source & $F$ & $\mathrm{df}$ & $\mathrm{p}$ \\
\hline (a) & & & \\
Time of day (T) & 4.78 & 4,28 & 0.025 \\
Day (D) & 0.55 & 4,28 & 0.606 \\
$\mathrm{~T} \times \mathrm{D}$ & 2.02 & 16,112 & 0.102 \\
& & & \\
(b) & & & \\
$\mathrm{T}$ & 2.46 & 4,28 & 0.112 \\
$\mathrm{D}$ & 0.15 & 2,14 & 0.752 \\
$\mathrm{~T} \times \mathrm{D}$ & 2.89 & 8,56 & 0.058 \\
\hline
\end{tabular}

The frequency of inspection among the 5 days varied significantly during the day (Table 2a) and was highest during the early morning (Fig. 1b). There were no differences in the frequency of inspection among the 5 days (Table 2a). The frequency of inspection in the 3 days in December-January did not differ among times of day and among days (Table 2b, Fig. 1b); therefore the mean frequency of inspection was calculated by averaging across times of day and days (45 inspections $/ 15 \mathrm{~min} \pm 1$ ). The estimated number of fish inspected by cleaner fish per day was $2297 \pm 83$ fish (the product of the mean frequency of inspection and the mean number of waking hours of Labroides dimidiatus).

The frequency of bites taken by Labroides dimidiatus was positively correlated with the duration of each inspection (Fig. 2), which shows that duration of inspection is a measure of feeding in $L$. dimidiatus. The total number of bites, the sum of the duration of

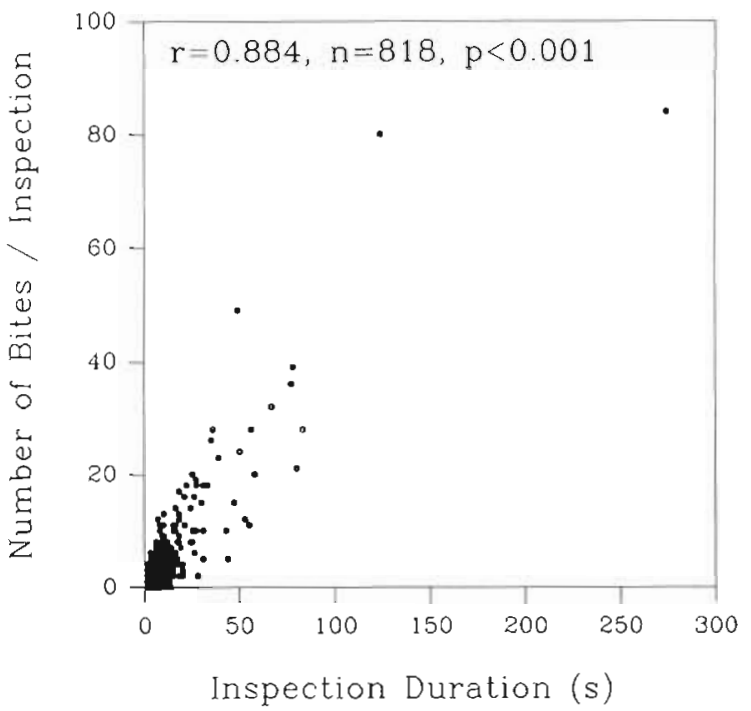

Fig. 2. Labroides dimidiatus. Number of bites taken by cleaner fish per inspection event compared with the duration of the inspection

inspection, and the frequency of inspection per observation follow a similar pattern of activity to each other throughout the day (Fig. 3). This shows that when the frequency of inspection and the duration of inspection were low, L. dimidiatus was also taking fewer bites and therefore eating less.

\section{Parasite ingestion rate}

Most of the parasites in the diet were gnathiid isopod larvae $(99.7 \pm 0.06 \%)$. The remainder consisted of a

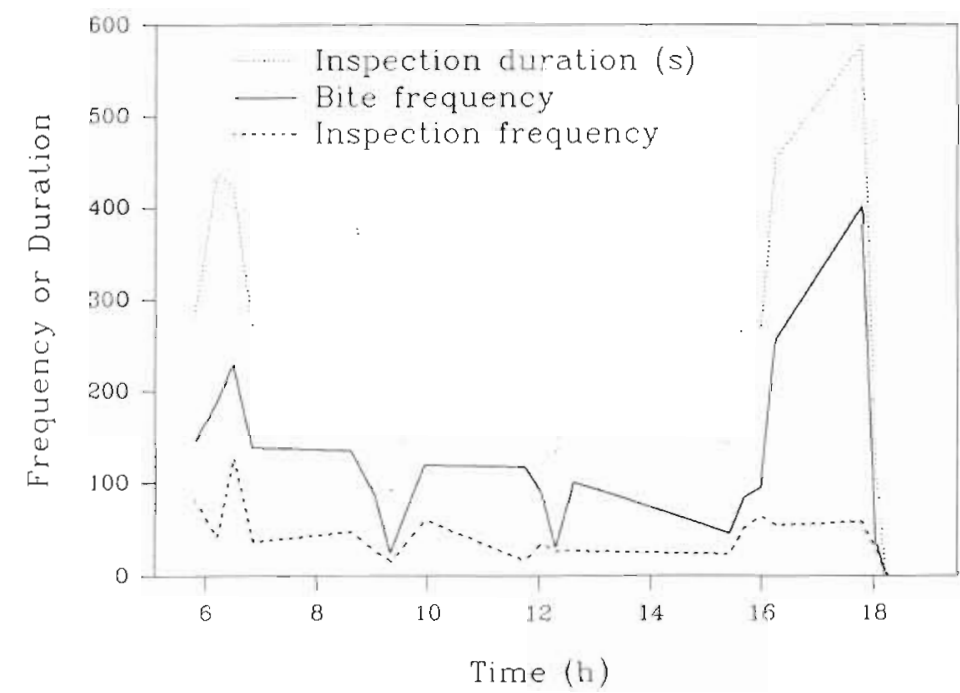

Fig. 3. Labroides dimidiatus. Simultaneous measurements of the feeding behaviour of cleaner fish throughout the day (27 October 1993) 


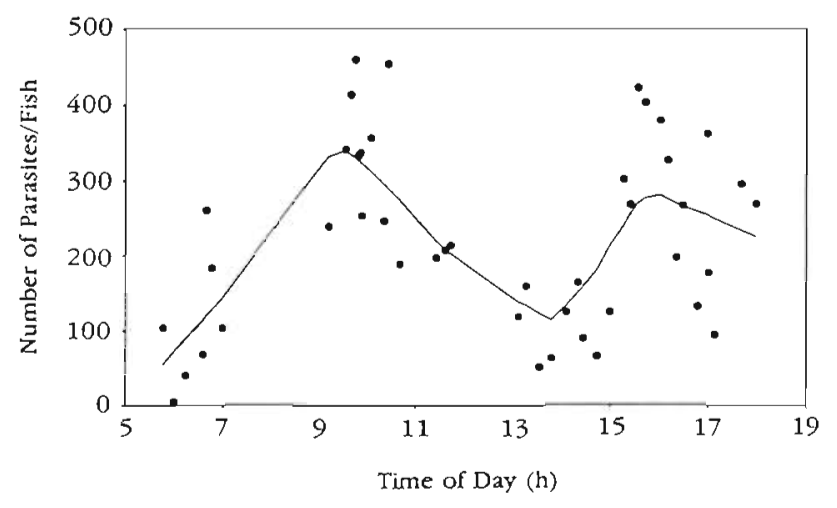

Fig. 4. Labroides dimidiatus. Total number of parasites in the digestive tract of cleaner fish used to calculate their parasite predation rate and total daily intake of parasites. Mean standard length of $L$. dimidiatus was $5.5 \pm 0.1$ (SE) cm

few caligid copepods and other parasitic copepods. The number of parasites in the diet throughout the day showed 2 peaks, one at 09:36 h and another at 16:00 h (LOWESS regression, $f=0.35$ ) (Fig. 4). The average number of parasites ingested by the time of the first peak was $343 \pm 26$. The amount of time Labroides dimidiatus spent inspecting fish from 06:18 to 09:36 h (at which time its gut was filled), was $72 \pm 3$ min

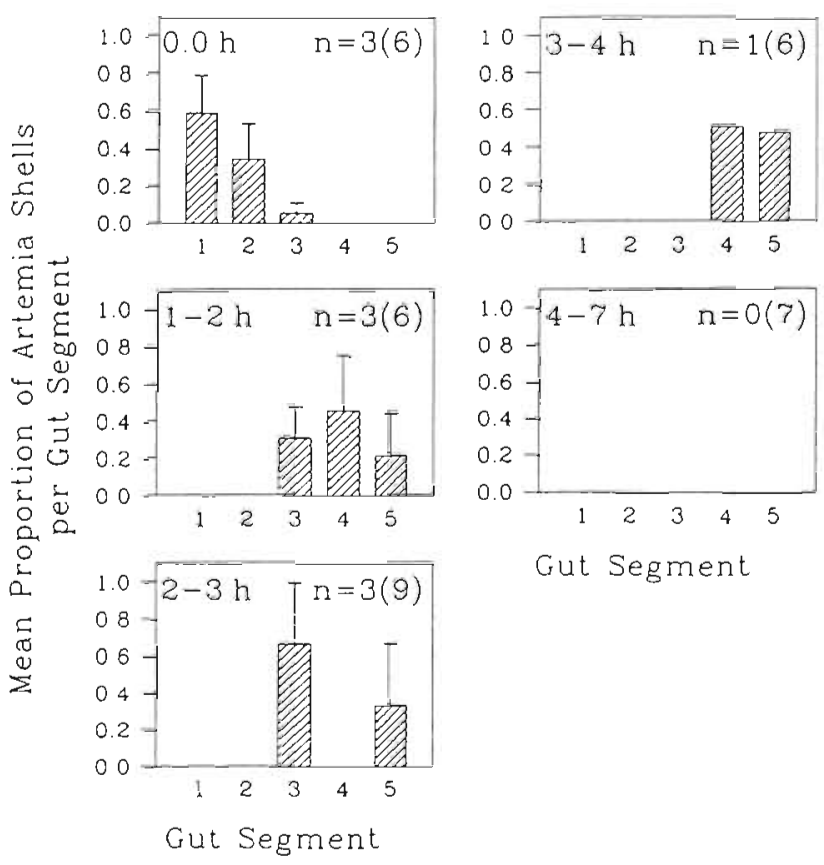

Fig. 5. Labroides dimidiatus. Mean proportion of empty shells of Artemia cysts $( \pm S E$ ) per gut segment of cleaner fish at different times. Sample sizes of guts containing cysts are provided; numbers in brackets are the total number of fish fed the Artemia mixture. Note: no fish $(n=9)$ recaptured more than $3.7 \mathrm{~h}$ after feeding on Artemia contained cysts. Mean standard length of $L$. dimidiatus was $5.4 \pm 0.1 \mathrm{~cm}$ (product of $303 \pm 13 \mathrm{~s}$ of inspection $/ 15 \mathrm{~min}$ and $3.57 \mathrm{~h}$ ). This gave an estimated predation rate of $4.8 \pm 0.4$ parasites eaten per minute of inspection (343 \pm 26 parasites $\mathrm{d}^{-1}$ divided by $72 \pm 3 \mathrm{~min}$ inspection $\mathrm{d}^{-1}$ ). When the predation rate was multiplied by the total duration. of inspection per day $(256 \pm 11 \mathrm{~min})$, the estimated total number of parasites eaten per cleaner fish per day was $1218 \pm 118$. Therefore, the number of parasites removed per inspection was $0.5 \pm 0.05$ (number of parasites eaten $d^{-1}$ divided by number of fish inspected $\mathrm{d}^{-1}$ ).

By the time cleaner fish had a full gut, roughly 6 bites were taken for every parasite eaten, which shows that not all bites involved the removal of parasites. This was estimated by dividing the total number of bites taken during the time interval (the product of the mean bite rate during this time interval and the time interval) by the number of parasites in a full gut.

\section{Gut clearance rate}

The maximal time required for food to pass through the gut was slightly over $3.7 \mathrm{~h}$ (Fig. 5). Cysts were found in the fifth segment 1.47 to $3.7 \mathrm{~h}$ after they were eaten while none of the 9 fish collected after this time had any cysts in their gut. Such a rate of digestion is consistent with the estimate of the total number of parasites eaten per day. Empty shells of Artemia cysts were easily distinguished throughout the gut. Although not all fish collected contained cysts, the number of fish which did was sufficient to estimate the time required for food to pass through the gut. Many of the guts without cysts contained Artemia nauplii, which indicates they were involved in the feeding experiment. However they were not used for estimating gut clearance rates as Artemia were only identifiable in the gut when in large quantities and only in the foregut.

\section{Number of parasites removed per fish per day}

An estimated $61 \pm 3$ parasites were removed per individual Hemigymnus melapterus (10 to $15 \mathrm{~cm}$ ) per day. These fish have, on average, $11 \pm 3$ gnathiids per individual

\section{Parasite infection rate}

The rate of infection of gnathiids onto fish was high The number of gnathiids on recaptured Hemigymnus melapterus was not significantly different from that on control fish [ANCOVA, Treatment: $F=1.26, \mathrm{df}=1,34$, 
$\mathrm{p}=0.269 ;$ covariate $(\mathrm{SL}): F=19.45, \mathrm{df}=1,34, \mathrm{p}<$ $0.001]$, which indicates that gnathiid abundance had returned to control levels during an interval of 1 to $16 \mathrm{~d}$ $188 \%$ of fish were collected within the first $6 \mathrm{~d}$ of releasing fish) (Fig. 6a). Because of the difficulties associated with finding and then collecting tagged fish, it was not possible to recapture fish at regular intervals. The total cumulative number of gnathiids recovered from treated fish (gnathiids in container plus on recaptured fish) was significantly higher than on control fish [ANCOVA, Treatment: $F=14.97$, df $=1,34$, $\mathrm{p}<0.001$; covariate (SL): $F=25.51$, df $=1,34, \mathrm{p}<$ $0.001]$. Thus gnathiids quickly recolonized treated fish after they were released (Fig. 6b). Placing control fish in a container lowered gnathiid numbers by $50 \pm 7 \%$. Parasite manipulations and tagging did not appear to alter the behaviour of the fish in the field as observations after their release indicated that they fed and behaved normally.

\section{DISCUSSION}

Labroides dimidiatus inspect a large number of fish and in the process feed on large numbers of parasites (mainly gnathiid isopods). The movement of gnathiids onto fish (infection) and off fish (mortality by predation from cleaner fish or emigration) is highly dynamic. The large number of gnathiids removed per individual fish on a daily basis, relative to the number of gnathiids on fish at a given time, shows that cleaner fish have an effect on the abundance of gnathiids on fish. However, more information on the carrying capacity of gnathiids on hosts and the processes involved in the infection of gnathiids onto fish is needed to determine to what extent gnathiid abundance is suppressed.

Labroides dimidiatus is an effective predator and removes, on average, 4.8 parasites (mainly gnathiids) $\mathrm{min}^{-1}$ inspection or 0.5 parasites for each fish inspection event. Individuals of some fish species are cleaned, on average, about 3 to 6 times per $30 \mathrm{~min}$ (e.g. Hemigymnus melapterus 10 to $15 \mathrm{~cm}$ SL are inspected 3.7 times/30 $\mathrm{min}$ ) (Grutter 1995a). The number of cleaning events individual fish experience may therefore be as high as 144 inspections d $^{-1}$ (Grutter 1995a). It is therefore likely that some fish have many parasites removed on a daily basis.

The number of parasites removed per fish inspected is similar to that of Losey (1974), who estimated that cleaner gobies in Puerto Rico ate 0.5 gnathiids per host fish. Losey also estimated that cleaner gobies in Puerto Rico ate 1.6 parasites $\mathrm{m}^{-2}$ reef area while Labroides phthirophagus in Hawaii ate only between 0.003 and 0.03 parasites $\mathrm{d}^{-1} \mathrm{~m}^{-2}$. Based on these large differences in predation rates, Losey (1974) concluded that
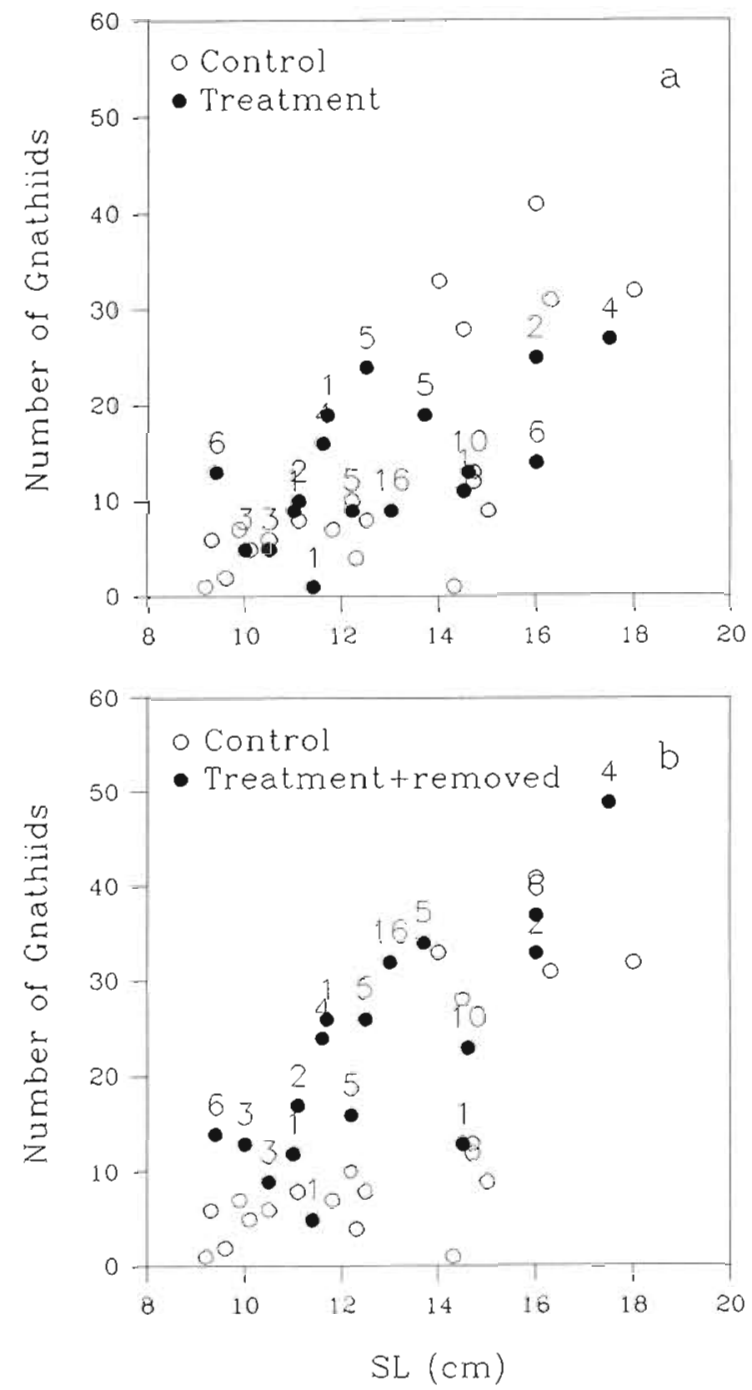

Fig. 6. Hemigymnus melapterus. Gnathiid isopod abundance on host fish of various lengths (SL), used for estimating gnathiid infection rates. (a) Number of gnathiids on control fish and on treated recaptured fish (1 to $16 \mathrm{~d}$ after their gnathiid loads were reduced by $50 \%$ ). (b) Number of gnathiids on control fish compared with the cumulative number of gnathiids recovered from treated fish (sum of the number of gnathiids on fish after 1 to $16 \mathrm{~d}$ plus the gnathiids removed on Day 0). Fish are labelled with the number of days from parasite manipulation to recapture

cleaning in Puerto Rico may be mutualistic. The predation pressure per unit area at Lizard Island appears to be much higher than that of Puerto Rico and Hawaii with an estimated 17.9 parasites eaten $\mathrm{m}^{-2} \mathrm{~d}^{-1}$ (based on $1.47 \mathrm{~L}$. dimidiatus $100 \mathrm{~m}^{-2}$; Green 1994). However, caution must be taken when making comparisons between these studies, as Losey's (1974) predation rates are based on gut contents and the abundance of cleaner fish and host fish, while this study was based on cumulative gut contents and the feeding behaviour of cleaner fish. 
The rate of infection by gnathiids onto Hemigymnus melapterus was relatively high. The abundance of gnathiids (which had been reduced by about $50 \%$ ) on treated fish quickly returned to levels of gnathiids found on control fish. Thus, on average, gnathiid abundance on fish doubled from the time fish were initially treated to when they were recaptured. The majority of treated fish (88\%) were recaptured within 6 d (Fig. 6). However, many of the total cumulative parasite loads on treated fish recaptured in less than $6 \mathrm{~d}$ appear to be higher than control fish (Fig. 6b). This suggests that the doubling of gnathiid abundance occurred in less than $6 \mathrm{~d}$. Other studies have found that gnathiids, which are only temporary parasites, remain on hosts for 'several hours' (Stoll 1962), 2 to 4 h or 1 or more days depending on site of attachment (Paperna \& Por 1977), and 2 to $24 \mathrm{~h}$ (Davies 1981). Thus complete reinfection of $H$. melapterus by gnathiids likely occurred in less than $6 \mathrm{~d}$.

By multiplying the predation rate by an estimate of the time that individual Hemigymnus melapterus spend being inspected by Labroides dimidiatus in a day, the number of parasites (mainly gnathiids) that were removed from an individual $H$. melapterus was estimated $(61 \pm 5)$. This number is about 6 times higher than the number of gnathiids found on individual hosts at a given time $(11 \pm 3)$. The removal of such a high number of gnathiids on a daily basis, relative to the low standing crop of gnathiids, is possible if the turnover rate of gnathiids on fish is high enough that gnathiids removed by cleaner fish are quickly replaced by other gnathiids. This study and other studies (Stoll 1962, Paperna \& Por 1977, Davies 1981) suggest that the infection rate of gnathiids can be relatively high.

Whether the predation rate has an impact on gnathiid abundance on Hemigymnus melapterus depends on the infection rate. The estimated infection rate in this study predicts a doubling in gnathiid abundance in 1 to $6 \mathrm{~d}$. This infection rate of gnathiids onto fish is little compared to the daily predation rate $(61 \pm 5)$, which is 6 times the standing crop of gnathiids. This suggests that gnathiid abundance on H. melapterus is suppressed by Labroides dimidiatus. Individuals of other fish species are cleaned as often as or even more than $H$. melapterus (Grutter 1995a) and also have gnathiids (Grutter 1994). Thus a similar effect of cleaner fish predation on gnathiids is to be expected on these fish species.

There is evidence that gnathiids mainly infect fish during the night (Potts 1973, Paperna \& Por 1977). It is therefore highly likely that a proportion of gnathiids removed by cleaner fish during the day may be replaced at night. If much infection occurs at night, the effect of cleaner fish on gnathiid abundance may be temporary and occur only during the day.
Despite heavy predation on gnathiids by cleaner fish, hosts still have gnathiids. Whether this abundance is lower than the maximum carrying capacity of gnathiids on hosts is crucial to understanding the extent to which cleaner fish suppress gnathiid abundances. High gnathiid densities on fish have been reported but these have been on captive fish (Paperna \& Por 1977, Mugridge \& Stallybrass 1983). Whether such high densities occur in the wild are unknown. The number of gnathiids on fish increases with the size of Hemigymnus melapterus (Fig. 6) and with the size of the fish species (Grutter 1994) suggesting an effect of space on the abundance of gnathiids. Studies on the effect of the absence of cleaner fish on gnathiid abundances are needed to resolve this question.

Possibly, the standing crop of gnathiids is related to the number of cryptic sites on fish. The time gnathiids remain on fish after engorgement varies according to the site of attachment, with gnathiids attached to the gills and pharyngeal chamber remaining on the fish much longer than those on the skin (Paperna \& Por 1977). This behaviour may be related to risk of predation, and may explain why reduced levels of gnathiids on treated fish did not keep increasing but 'stabilized' at numbers similar to those on controls.

The predation estimates assume that parasites are evenly distributed among fish. However, this is unlikely as parasite loads and species composition are often host-specific (Grutter 1994). Labroides dimidiatus also feeds selectively on gnathiids (Grutter 1995b), whose abundance often varies according to the size of fish (Fig. 6, Grutter 1994). Furthermore, L. dimidiatus foraging efficiency probably varies among fish species due to differences in host fish morphology and behavioural responses among species. Therefore, the number of parasites $L$. dimidiatus obtains per unit time probably varies among fish sizes and species.

Higher rates of feeding by cleaner fish in the morning may be due to several factors. Labroides dimidiatus may become satiated after feeding at a rapid rate and respond by lowering its feeding rate. This has been shown for skipjack tuna, which reduces its responsiveness to food when its stomach is half full (Magnusen 1969). Alternatively, since host fish have some control over the outcome of a cleaning interaction (Losey 1971), the possibility arises that the behaviour of hosts may influence the feeding behaviour of $L$. dimidiatus. Potts (1973) suggested that hosts were more available in the morning as a result of increased infection of gnathiids at night. Although a preliminary investigation has revealed no significant effect of time of day on individual host cleaning rates (Grutter 1995a), only 7 host fish species were examined. Finally, coral reef fish often behave differently in the morning and/or at nightfall compared to midday (Polunin \& Klumpp 1989, 
Hobson 1991, Choat \& Clements 1993). The fact that the frequency of inspection varied more among times of day than the duration of inspection suggests that factors which influence host fish abundance influence how many fish cleaners inspect.

Although the duration of inspection among days and the interaction term (Time of day and Day) for the frequency of inspection in December-January were almost significant (Tables $1 \mathrm{~b} \& 2 \mathrm{~b}$ ), both were averaged across times of day and days. This may have introduced some error into the estimates of daily duration and frequency of inspection. More studies are needed to examine temporal variation in the inspection variation of Labroides dimidiatus.

The longer duration of inspection by Labroides dimidiatus in July (Fig. 1a) suggests there may be seasonal variation in feeding rates. There is considerable temporal variation among months in the abundance of gnathiids in the diet of $L$. dimidiatus, and in the size frequency distribution of gnathiids in the diet and on a host fish Hemigymnus melapterus (Grutter 1995b). Such temporal changes in the diet probably coincide with changes in foraging patterns and feeding rates. Although there was little variation in the duration of inspection among days in December-January, the feeding rates in July were only recorded on 1 day and must therefore be interpreted cautiously. More observations at different times are needed to determine whether there is seasonal variation in feeding rates of L. dimidiatus.

The number of gnathiids consumed daily per cleaner fish, when converted to biomass $(223 \mu \mathrm{g}$ ) (following Grutter 1995b), is $7 \%$ of the body weight of Labroides dimidiatus. This estimate agrees with the estimates of the daily requirements of similar sized fish (Daan 1973, Ruggerone 1989). Organisms similar to gnathiids, crustacean zooplankton, are high in protein (Parsons \& Takahashi 1973). These suggest gnathiids probably provide the bulk of the food requirements of $L$. dimidiatus.

The bimodal pattern of parasite abundance in the diet throughout the day may be due to changes in feeding rates throughout the day and to a delay in gastric emptying. If feeding rates (and defecation rates) are constant, then parasite abundance in the gut should reach an asymptote. Instead, parasite abundance increased rapidly in the morning while feeding rates were high, and then, although the numbers of parasites in the diet did appear to reach a maximum (at 09:36 h), the number of parasites in the gut dropped. This drop is probably partly due to reduced feeding rates at this time and to the gut clearance rate. Assuming that gastric emptying continued at a constant rate, the continued decline in parasite abundance in the gut during midday suggests that the intake of parasites was reduced as a result of depressed feeding rates. This is reinforced by the increase in parasite abundance in the gut which coincided with an increase in feeding rates. Such variable patterns in gut contents have important implications for the timing of sampling of gut contents.

The time required for food to pass through the digestive tract (about $3.7 \mathrm{~h}$ ) agrees with a similar gut clearance study which also used labelled food, fish that fed continuously and were of a similar size to Labroides dimidiatus, and a similar water temperature (Noble 1973). The rate is consistent with and therefore corroborates the estimate of the total number of parasites eaten per cleaner fish per day.

This study suggests that cleaner fish suppress gnathiid abundances on fish. Whether hosts benefit from the removal of gnathiids depends on their effect on hosts. The effects of gnathiids on hosts vary, ranging from slight blemishes (Davies 1981) and lesions (Monod 1926), to heavy inflammation and hypertrophy of tissues (Honma et al. 1991), and death (Paperna \& Por 1977, Mugridge \& Stallybrass 1983). The latter deleterious effects, however, occurred in captivity (Paperna \& Por 1977, Mugridge \& Stallybrass 1983) and involved large gnathiids (Paperna \& Por 1977. Honma et al. 1991). Gnathiids at Lizard Island are relatively small (Grutter 1994) and therefore may not be as damaging to the host. There is circumstantial evidence that gnathiids may be a vector for the blood parasite Haemogregarina bigemina but this has not been refuted nor substantiated (Davies \& Johnston 1976). Whether gnathiid parasites have any lasting effect on the health of host fish is therefore unclear.

Acknowledgements. I am indebted to F. Grutter, E. Hutchison, and M. Johnson for their enthusiastic help in the field and/or laboratory. Many thanks to J. H. Choat, T. Hughes, G. Jones, D. Bellwood, R. Rowe, and anonymous reviewers for their constructive comments on earlier drafts of the manuscript. I am very grateful to $\mathrm{R}$. Alford, G. De'ath, and N. Moltschaniwskyj, who provided invaluable statistical advice. This work benefitted greatly from discussions with $\mathrm{J}$. H. Choat and D. Bellwood. Funding was provided by the Australian Museum in the form of a Postgraduate Grant 1992 and a Lizard Island Research Station Doctoral Fellowship 1993-1994. This is a contribution from the Lizard Island Research Station, a facility of the Australian Museum.

\section{LITERATURE CITED}

Choat JH, Clements KD (1993) Daily feeding rates in herbivorous labroid fishes. Mar Biol 117:205-211

Daan N (1973) A quantitative analysis of the food intake of North Sea cod, Gadus morhua. Neth J Sea Res 6(4): $479-517$

Davies AJ (1981) A scanning electron microscope study of the praniza larva of Gnathia maxillaris Montagu (Crustacea, Isopoda, Gnathiidae), with special reference to the mouthparts. J natl Hist 15:545-551 
Davies AJ, Johnston MRL (1976) The biology of Haemogregarina bigemina Laveran \& Mesnil, a parasite of the marine fish Blennius pholis Linnaeus. J Protozool 23(2):315-320

Gorlick DL, Atkins PD, Losey GS (1987) Effect of cleaning by Labroides dimidiatus (Labridae) on an ectoparasite population infecting Pomacentrus vaiuli (Pomacentridae) at Enewetak Atoll. Copeia 1:41-45

Green AL (1994) The early life history of labroid fishes at Lizard Island, Northern Great Barrier Reef. PhD thesis, James Cook University, Townsville

Grutter AS (1994) Spatial and temporal variations of the ectoparasites from seven reef fish species from lizard Island and Heron Island, Australia. Mar Ecol Prog Ser 115: $21-30$

Grutter AS (1995a) Relationship between cleaning rates and ectoparasite loads in coral reef fishes. Mar Ecol Prog Ser 118:51-58

Grutter AS (1995b) Parasites in the cleaning interactions between the cleaner wrasse Labroides dimidiatus and fish. PhD thesis, James Cook University, Townsville

Grutter AS (1996a) Experimental demonstration of no effect by the cleaner wrasse Labroides dimidiatus (Cuvier and Valenciennes) on the host fish Pomacentrus moluccensis (Bleeker). J exp mar Biol Ecol (in press)

Grutter AS (1996b) A comparison of methods for sampling ectoparasites from coral reef fishes. Mar Freshwat Res 46 (in press)

Hobson ES (1991) Trophic relationships of fishes specialized to feed on zooplankters above coral reefs. In: Sale P (ed) The ecology of fishes on coral reefs. Academic Press, Inc, San Diego, p 69-95

Honma Y, Tsunaki S, Chiba A, Ho J (1991) Histopathological studies on the juvenile gnathid (Isopoda, Crustacea) parasitic on the branchial chamber wall of the stingray, Dasyatus akajei, in the Sea of Japan. Rep Sado mar Biol Stn, Niigata Univ 21:37-47

Limbaugh C (1961) Cleaning symbiosis. Scient Am 205:42-49

Losey GS (1971) Communication between fishes in cleaning symbiosis. In: Cheng TC (ed) Aspects of the biology of symbiosis. University Park Press, Baltimore

Losey GS (1972) The ecological importance of cleaning symbiosis. Copeia 4:820-833

Losey GS (1974) Cleaning symbiosis in Puerto Rico with comparison to the tropical Pacific. Copeia 4:960-970

This article was presented by C. Birkeland, Mangilao, Guam
Magnuson JJ (1969) Digestion and food consumption by skipjack tuna (Katsuwonus pelamis). Trans Am Fish Soc 98(3): 379-392

Maxwell SE, Delaney HD (1990) Designing experiments and analyzing data. Wadsworth Publishing Co, Belmont

Monod, T (1926) Les Gnathiidae. Essai monographique (morphologie, biologie, systématique). Mem Soc Sci nat du Maroc 13:1-668

Mugridge RER, Stallybrass HG (1983) A mortality of eels, Anguilla anguilla L., attributed to Gnathiidae. J Fish Biol $6: 81-82$

Noble RL (1973) Evacuation rates of young yellow perch. Perca flavescens (Mitchill). Trans Am Fish Soc 4 $759-763$

Paperna I, Por FD (1977) Preliminary data on the Gnathiidae (Isopoda) of the northern Red Sea, the Bitter Lakes and the eastern Mediterranean and the biology of Gnathia piscivora n. sp. Rapp Comm int Mer Mediter 24(4):195-197

Parratt LG (1966) Probability and experimental errors in science. John Wiley and Sons, Inc, New York, p 109-118

Parsons TRK, Takahashi M (1973) Biological oceanographic processes. Pergamon Press, Oxford

Polunin NVC, Klumpp DW (1989) Ecological correlates of foraging periodicity in herbivorous reef fishes in the Coral Sea. J exp mar Biol Ecol 126:1-20

Potts GW (1973) Cleaning symbiosis among British fish with special reference to Crenilabrus melops (Labridae). J mar biol Ass UK 53:1-10

Ruggerone GT (1989) Gastric evacuation rates and daily ration of piscivorous coho salmon, Oncorhynchus kisutch Walbaum. J Fish Biol 34:451-463

SAS (1991) SAS ${ }^{(3)}$ system for linear models, 3rd edn. SAS Institute, Inc, Cary, NC

Stoll C (1962) Cycle évolutif de Paragnathia formica (Hesse) (Isopode-Gnathiidae) Cah Biol mar 3:401-416

Treasurer J (1994) Prey selectivity and daily consumption by a cleaner fish, Ctenolabrus rupestris (L.), on farmed Atlantic salmon, Salmo salar L. Aquaculture, Amsterdam 122: $269-277$

Trexler JC,Travis J (1993) Nontraditional regression analyses. Ecology $74(6): 1629-1637$

Youngbluth MJ (1968) Aspects of the ecology and ethology of the cleaning fish, Labroides phthirophagus Randall. Z Tierpsychol 25(8):915-932

Manuscript first received: December 13, 1994

Revised version accepted: March 27, 1995 